Participatory Educational Research (PER)

Special Issue 2016-II, pp., 143-156; 01 February 2016

Available online at http://www.partedres.com

ISSN: 2148-6123

http://dx.doi.org/10.17275/per.16.spi.2.16

\title{
The Impact of Elective Application of Science Lessons on Sciences Courses: A Qualitative Study of 6th Grade Students
}

\author{
Pınar URAL KELEŞ ,Mehmet Akif HAŞILOĞLU, Süleyman AYDIN* and \\ Ayşegül ÖNER \\ A ğrı Ibrahim Çeçen University, A ̈̆rı, Turkey
}

\begin{abstract}
This study was conducted with the aim of identifying the impact of elective Application of Science lessons on science courses, based on the opinions of students. The study sample comprised fifteen volunteer 6th Grade students at secondary education level from a school in the Turkish province of Ağr1, who were given elective Application of Science lessons during the spring semester of the 2014/15 academic year. The data of this qualitative study was collected using the semi-structured interview technique, in accordance with the case study method. The data collected by the interviews were subjected to descriptive and content analysis. Results of the study showed that students enjoyed the elective Application of Science lessons and that they would like to take the subject again in the next grade level as it made it easier for them to learn topics related to science and contributed to their successful performance in science. The study also found that the elective Application of Science lessons were utilized to solve experiments or to teach topics in other science activities. Among other recommendations, it is emphasized that the teacher's guidebook for elective Application of Science lessons, for all grade levels $(5,6,7,8)$, should be published as soon as possible.
\end{abstract}

Keywords: Elective application of science lessons, science, student opinions

\section{Introduction}

The development of scientific perspective involves the enhancement of an individual's ability to research and question, and to apply critical thinking to problem solving and decision making skills, to be a lifelong learner, and to continue their curiosity of close and distant environments. The scientific perspective of an individual can be made possible by ensuring that they gain the knowledge, understanding, attitudes and values related to science. Thus, in recent years, many countries have adopted the general aim of educating individuals to gain a scientific perspective, or in other words, to ensure scientific literacy, especially through the teaching of science in schools (MoNE, 2013a).

The concept of scientific literacy, which has had a place in the curricula of developed countries for many years, was incorporated into the Turkish Science and Technology syllabus in 2005. In order to educate individuals who are more inclined to the application of science, that is individuals who are scientifically literate, in addition to revising the Science and

\footnotetext{
* Education, Science Education Department, yupul@ hotmail.com
} 
Technology syllabus as the 'science subject', some other provisions were recently made. One of these changes was the decision by the Ministry of National Education (MoNE), dated 08.05.2013, to add new elective subject to the weekly school timetable for the lower secondary level of primary education institutions. One of the elective subjects added to the Science and Mathematics curriculum was the Application of Science lesson (URL-1, 2014). With this elective course, it is expected that the students' creativity will increase, their imagination and investigative characteristics will develop, their performance in other subjects will improve accordingly as they gain the opportunity to apply what they learn to their lives. The means by which the learning objectives of the elective Application of Science lessons (EASL) can be reached, is by ensuring that the students acquire the skills of scientific process. The following are the main principles of the Application of Science lessons and the scientific processing skills that the students are expected to acquire (MoNE, 2013b):

Planning and starting: observation, comparison and categorization, making inferences, estimation, predication, identifying variables

Implementation: designing the experiment, knowing and utilizing materials, tools and equipment for experiments, collecting information and data, taking measurements, recording data

Analysis and conclusions: data processing and development of a model, interpretation and drawing conclusions, presentation

A review of the relevant literature found that there are only a limited number of studies conducted regarding EASL in Turkey, as the course has only recently been included in the secondary education curriculum (Yerer, et al, 2013; Eke, 2013; Bozdoğan \& Şengül, 2014; Yırtıc1, 2014; Ural Keleş, Aydın \& Öner, 2015). The current situation of science education in Turkey, and the limited number of studies conducted in this field, only highlights the significant impact that this elective course will have on Science in Turkish schools. With this as the starting point the current study was conducted with the aim of identifying the opinions of students as a means of determining the impact of EASL on Science courses.

\section{Method}

This research used the case study method, which provided the opportunity to apply an in-depth investigative approach. The case to be studied can be a school, an individual or a particular group (Wellington, 2000). This method focuses on the characteristics of the case in question and allows for various data collection techniques to be used simultaneously (Cohen \& Manion, 1994; Çepni, 2009).

The reason for opting for the case study method in this qualitative study was the wish to conduct an in-depth study of 6th Grade students' opinions regarding the impact of EASL on science courses.

\section{Sample}

The study sample comprised fifteen 6th Grade students at secondary education level from a school in the Turkish province of Ağrı, who were given elective Application of Science lessons during the spring semester of the 2014/15 academic year. The students were included in the study on a voluntary basis. 


\section{Data Collection and Analysis}

The tool used for data collection in the study was the semi-structured interview technique. The subjects to be interviewed were randomly selected from students taking the elective Application of Science lessons (EASL). Students participating in the interviews were coded as S1, S2, S3, ... S15, within the framework of ethical research. A total of nine questions were asked to all the students in the interviews, which lasted for approximately 2025 minutes. A review of the literature was conducted before the questions for the interviews were prepared (Çavuş \& Öztuna, 2013; Yerer, et al, 2013; Eke, 2013; Bozdoğan \& Şengül, 2014; Yırtıc1, 2014; Ural Keleş, Aydın \& Öner, 2015). When the structure of the questions was determined, opinions were sought from two academics in the field. In parallel to this process, the opinions of three science and technology teachers assigned to these courses in the schools were also sought. Once the questions were prepared, unstructured interviews were held with a few students and the questions were finalized according to the results. The consent of the participants was obtained to make voice recordings of the interviews. The recorded data from the interviews were then transcribed. Data obtained as a result of the interviews were subject to descriptive and content analysis. Content analysis is a systematic technique that relies on coding the text according to various rules and developing a summary of the text by means of small-scale content categories (Büyüköztürk, 2004: s,195). The data obtained from the content analysis was used to develop matrices. In the descriptive analysis, the data was organised to take the opinions of students' data from the interviews were analyzed by taking into consideration the level of significance and importance and, in certain cases, various statements were taken exactly in quotation marks.

\section{Findings}

This section of the study presents the findings obtained from the semi-structured interviews held with the aim of determining the opinions of students taking the elective application of science lessons regarding the science course. Nine questions were asked of the students in the interviews and the data obtained was subject to content and descriptive analysis. Data obtained as a result of the content analysis was used to establish nine matrices. The findings are presented below in a format that presents the interview question, followed by the students' opinions.

\section{Question 1. Do you enjoy EASL? Why?}

The responses of 14 students who stated that they enjoyed EASL were analyzed and the codes "a lot of fun", "preparation for science lessons", "feels comfortable with the lecture" and "enjoys experiments" and the codes "does not enjoy experiments" and "hates experiments" for those students who stated they did not enjoy EASL were established and are represented in the matrix in Table 1.

Table 1. Students' opinions about whether they enjoyed EASL or not

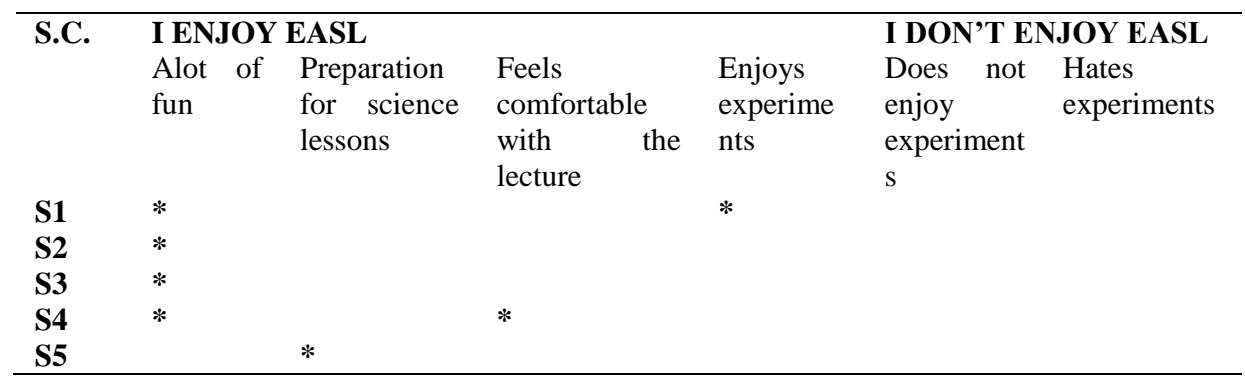




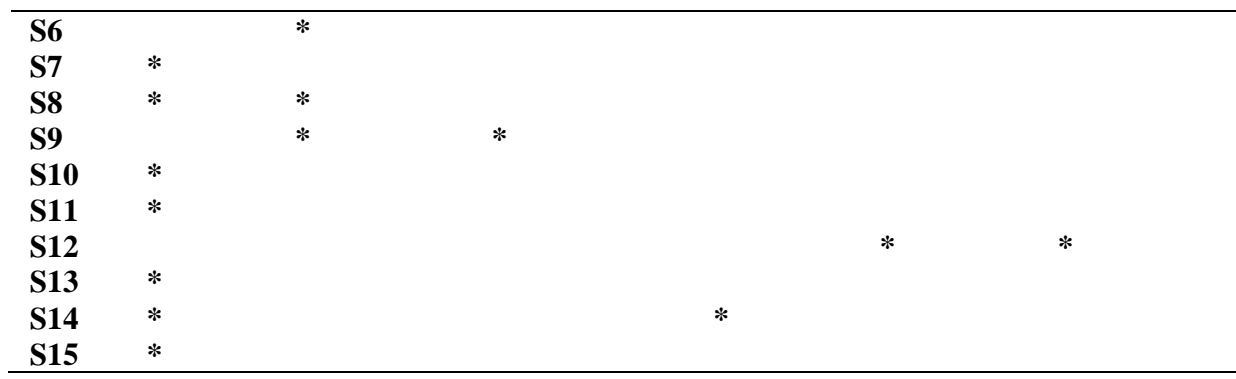

\section{S.C: Student Code}

\section{EASL: Elective Science Applications Lecture}

An examination of Table 1, which is a matrix of opinions of $6^{\text {th }}$ Grade students taking EASL on whether they enjoy EASL and why they enjoy it, shows that out of a total of 15 students, 14 students enjoyed the application of science lessons and only one didn't. When asked why they enjoyed the EASL lessons, 11 students stated that the lessons are "a lot of fun", 4 students stated it was "preparation for science lessons", two students stated that it makes them "feel comfortable" and two students stated that they "enjoyed experiments", with use of these codes, while the codes "does not enjoy experiments" and "hates experiments" was applied to one student and used to state the reasons for which they did not enjoy EASL. The opinion of S4 to this question can be seen below.

\section{I: Do you enjoy EASL? Why?}

S4: I slowly came to enjoy the elective science applications lessons, in time I felt comfortable and it wasn't in the beginning but now it is enjoyable and fun.

\section{Question 2. Does EASL have an effect on whether you like science lessons?}

The result of the analysis to this question led to the formation of two preliminary codes: "EASL has an effect on whether I like science lessons" and "I don't like science lessons; EASL has no effect." Following this, taking the responses of the students who stated that EASL had an effect on whether they enjoyed science lessons, the matrix given in Table 2 was established by using the codes, "EASL has no effect, I liked science anyway", "because it is related to technology", "we always do activities in EASL", EASL makes science easier", EASL keeps science knowledge fresh", EASL makes science lessons more enjoyable" and "I perform better in science lessons because of EASL". 
Table 2. Students' opinions on whether EASL has an effect on whether they like science lessons

\begin{tabular}{|c|c|c|c|c|c|c|c|c|}
\hline & EASL HA & AN EFFEC & ON WHET & IER I LIKE SC & NCE LE & $\overline{\mathrm{DNS}}$ & & $\begin{array}{lll}\hat{I} & \text { don't like }\end{array}$ \\
\hline & $\begin{array}{l}E A S L \text { had } \\
\text { little } \\
\text { effect, I } \\
\text { liked } \\
\text { science } \\
\text { anyway }\end{array}$ & $\begin{array}{l}\text { We always } \\
\text { do } \\
\text { activities } \\
\text { in EASL }\end{array}$ & $\begin{array}{l}\text { Because } \\
E A S L \text { is } \\
\text { related to } \\
\text { technolog } \\
\mathrm{y}\end{array}$ & $\begin{array}{l}\text { EASL makes } \\
\text { it easier to } \\
\text { understand } \\
\text { science }\end{array}$ & $\begin{array}{l}E A S L \\
\text { keeps } \\
\text { science } \\
\text { knowled } \\
\text { ge fresh }\end{array}$ & $\begin{array}{l}E A S L \\
\text { ensures } \\
\text { that } \\
\text { science } \\
\text { lessons } \\
\text { become } \\
\text { more } \\
\text { enjoyabl } \\
\text { e }\end{array}$ & $\begin{array}{l}\text { I perform } \\
\text { better in } \\
\text { science } \\
\text { lessons } \\
\text { because of } \\
\text { EASL }\end{array}$ & $\begin{array}{l}\text { I don't science } \\
\text { lessons } \\
\text { EASL has not } \\
\text { effect on whether } \\
\text { I like science } \\
\text { lessons more }\end{array}$ \\
\hline S1 & & & & & & & $*$ & \\
\hline S2 & & & & $*$ & & $*$ & & \\
\hline S3 & & $*$ & * & & $*$ & & & \\
\hline S4 & & & & $*$ & & & & \\
\hline S5 & $*$ & $*$ & & $*$ & & & $*$ & \\
\hline S6 & & & & $*$ & $*$ & & & \\
\hline S7 & & & & $*$ & $*$ & $*$ & $*$ & \\
\hline S8 & & & $*$ & $*$ & $*$ & $*$ & $*$ & \\
\hline S9 & & & & & $*$ & & & \\
\hline $\mathrm{S} 10$ & & * & & $*$ & & & & \\
\hline $\mathrm{S} 11$ & & & & & & & & \\
\hline $\mathrm{S} 12$ & & & & & & & & $*$ \\
\hline $\mathrm{S} 13$ & $*$ & & & & & & & \\
\hline $\mathrm{S} 14$ & & & & $*$ & $*$ & & $*$ & \\
\hline $\mathrm{S} 15$ & & & & $*$ & & & & \\
\hline
\end{tabular}

S.C: Student Code

EASL: Elective Science Applications Lecture

An examination of Table 2 shows that, 14 out of the 15 students who participated in the interviews were of the opinion that EASL had an impact on whether science lessons were liked or not. Only one student stated that they did not like science lessons anyway and thus EASL has no effect. With regard to how EASL had an impact on whether they liked science lessons or not, the most common statement used by nine students was that EASL makes science easier to understand and six students stated that EASL kept their science knowledge fresh. In this sense, the statements least used was by two students who stated that it was because EASL was related to technology. Furthermore, two students stated that EASL had an impact, even if only a little, on the liking of science lessons. The comments of S5, for this question, is given below.

\section{I: Does EASL have an effect on whether you like science lessons?}

S5: Yes it does.

\section{I: How?}

S5: I used to like science lessons anyway, but after the EASL lessons, I enjoy them even more because we always do activities; they make it easier for me to understand the topics, my grades in science are much better now.

\section{Question 3. Does EASL make it easier for you to learn topics in science? How?}

An analysis of the responses provided by the interviewed students regarding the contribution of EASL to science lessons were coded as follows: "a repeat of the science lecture", "conducting activities on the topics of the science lessons", "preparation for science lessons", "permanent learning with experiments", "ease of asking questions about what was 
not understood", "conducting different activities", "undertaking topics which could not be taught in the science lessons due to lack of time". The matrix in Table 3 was established according to these codes.

Table 3. Students' opinions regarding the impact of EASL on learning topics in science

\begin{tabular}{|c|c|c|c|c|c|c|c|}
\hline \multirow[t]{2}{*}{ S.C. } & \multicolumn{6}{|c|}{ IT MAKES SCIENCE LESSONS EASIER } & \multirow[b]{2}{*}{$\begin{array}{l}\text { Undertaking } \\
\text { topics which there } \\
\text { was not enough } \\
\text { time to teach in } \\
\text { the science } \\
\text { lessons }\end{array}$} \\
\hline & $\begin{array}{l}\text { A repeat } \\
\text { of the } \\
\text { science } \\
\text { lesson }\end{array}$ & $\begin{array}{l}\text { Conducting } \\
\text { activities on } \\
\text { topics of the } \\
\text { science } \\
\text { lessons }\end{array}$ & $\begin{array}{l}\text { It is } \\
\text { preparation } \\
\text { for science } \\
\text { lessons }\end{array}$ & $\begin{array}{l}\text { Permanent } \\
\text { learning } \\
\text { with } \\
\text { experiments }\end{array}$ & $\begin{array}{l}\text { Easy to ask } \\
\text { questions/topics } \\
\text { not understood }\end{array}$ & $\begin{array}{l}\text { Conducting } \\
\text { different } \\
\text { activities }\end{array}$ & \\
\hline S1 & $*$ & & & & $*$ & & $*$ \\
\hline S2 & $*$ & & & & & & \\
\hline S3 & & $*$ & & & & & $*$ \\
\hline S4 & & & $*$ & & & & \\
\hline S5 & $*$ & $*$ & & $*$ & & & \\
\hline S6 & * & & & & & & * \\
\hline S7 & $*$ & & & & & & \\
\hline S8 & $*$ & & & & & & \\
\hline S9 & $*$ & & & & & & \\
\hline S10 & & $*$ & & & & & \\
\hline S11 & $*$ & & $*$ & $*$ & $*$ & & \\
\hline S12 & $*$ & & & $*$ & & & \\
\hline S13 & $*$ & & & $*$ & & & \\
\hline S14 & $*$ & & & & & & \\
\hline S15 & & $*$ & & & & $*$ & \\
\hline
\end{tabular}

S.C: Student Code

EASL: Elective Science Applications Lecture

A review of the matrix in Table 3 shows that, the most common statement used by 11 interviewed students was "a repeat of the science lesson." "Conducting different activities" was a statement made by one of the students. The opinions of S11 to this question, is given below.

\section{I: Does EASL make it easier for you to learn topics in science? How?}

S11: I believe that EASL is a repeat of what we learn in the science lessons. We sometimes prepare for the topics on the science lesson, sometimes we conduct the experiments we were not able to do in the lessons; we have a more lasting learning experience with the experiments, we can ask the teacher about the topics which were not understood.

\section{Question 4. Does EASL make science lessons easier to understand? Why?}

The codes "repeating science in EASL," "conducting different experiments related to science," "solving different tests related to science topics," "activities make it easier to understand", "easily asking questions in EASL", and "EASL and science lesson topics are similar to each other" were established from student responses and the matrix in Table 4 was prepared. 
Table 4. Students' opinions regarding the impact of EASL on better understanding of the

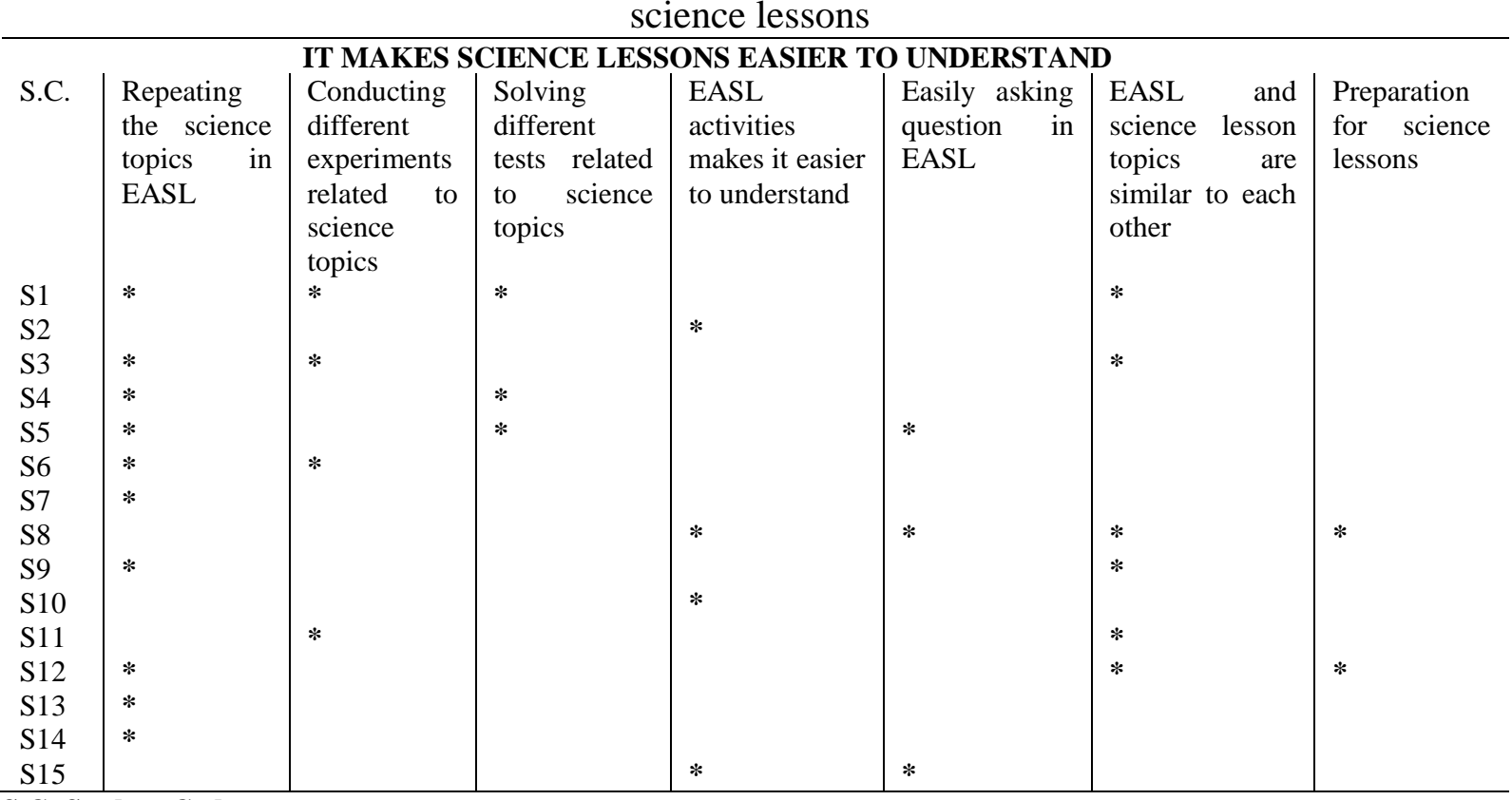

S.C: Student Code

EASL: Elective Application of Science lesson

S12: Sometimes EASL is a preparation for science topics because we repeat the topics or have similar lessons and therefore it makes it easier to understand the topics of the science lessons.

\section{Question 5. Which of the experiments you conducted in EASL do you remember most? Did you benefit from this activity in science lessons? How?}

The codes "making models and solving tests in systems," "in temperature, we conducted experiments," "we conducted experiments in audio," "in electricity we made circuits," "in temperature we conducted experiments with mirrors" and "we solved tests about force and motion" are presented to the reader as a result of the analysis conducted on the interview responses of the students. The manner in which the students gained benefit in science lessons as a result of activities were given the codes of "higher level of participation in science lessons," "completing project work" and "I benefitted from it in the science exam." Table 5 shows the matrix for the codes established as a result of the analysis.

Table 5. Students' Opinions regarding EASL activities and how students benefited from these activities in science lessons

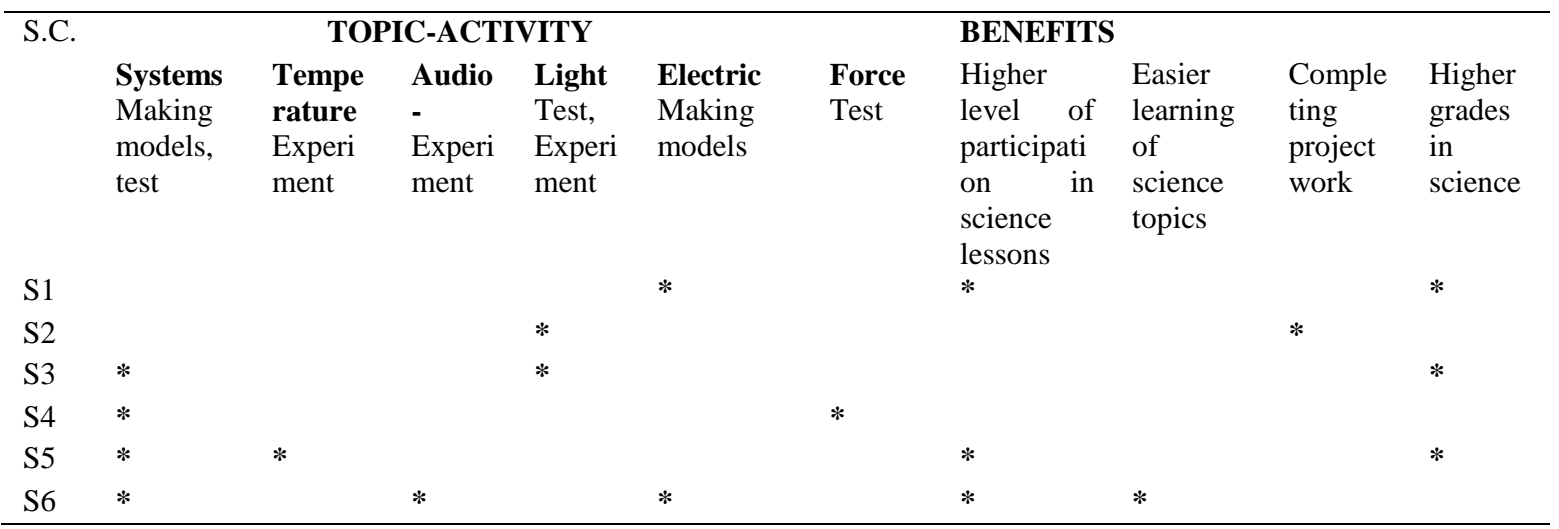




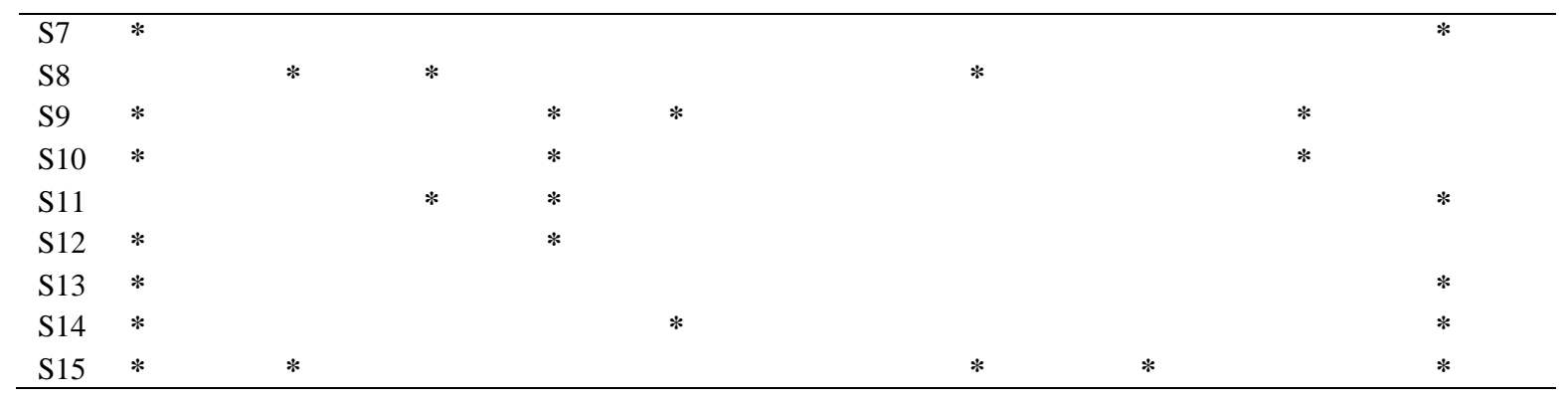

S.C: Student Code

EASL: Elective Application of Science lessons

Analysis of data from student interviews showed that activities were conducted on many different topics in EASL. Among these, systems were the highest ranked, with 11 student responses. In addition, the table shows that there are activities and experiments conducted under the topic headings of audio, electricity, temperature, force and motion. It is understood from the students' responses that solving different tests are among EASL activities. Eight students stated that these activities were reflected in their higher grades in the science exam. In addition, among the students' opinions was that the activities were beneficial in their higher participation in class and supported their project work. The opinions of S5 and S6 for this question are given below.

I: Which of the experiments you conducted in EASL do you remember most? Did you benefit from this activity in science lessons? How?

S5: For example, we made models about systems, in the topic of force we solved different tests. We solve tests on each topic. We did an experiment about electricity.

I: What kind of an experiment?

S5: We made a model of a circuit.

I: What did you learn as a result of making this model? What was its benefit to you in the science lessons?

S5: I learnt about circuit elements and open and closed circuits with this model. I now speak more in the science lessons, and my grades have increased.

I: How are the activities conducted in EASL reflected in the science lessons?

S6: I have become more participative in science lessons due to the things that I learnt in the activities conducted in the EASL, I'm finding learning easier, I saw its advantage in the science exam.

Question 6. In your opinion, how would the level of your performance in the science course differ if you hadn't taken EASL?

The codes "lower" and "no change" were assigned as a result of the analysis of interview responses of students and the matrix in Table 6 was established.

Table 6. Students' opinions as to how their level of performance in science would change if they had not have taken EASL

$\begin{array}{llllllllllllllll} & \text { S1 } & \text { S2 } & \text { S3 } & \text { S4 } & \text { S5 } & \text { S6 } & \text { S7 } & \text { S8 } & \text { S9 } & \text { S10 } & \text { S11 } & \text { S12 } & \text { S13 } & \text { S14 } & \text { S15 } \\ \text { Lower } & * & * & * & * & * & * & * & * & * & * & * & * & * \\ \text { No change } & & & & & & & & & & & & & & & \end{array}$

S.C: Student Code

EASL: Elective Application of Science lessons

As can be seen in Table 6, out of the 15 students participating in the study, 14 students stated that their level of performance in science would drop if EASL were not taken, while only one student stated that their level of performance would not change. 


\section{Question 7. Does taking EASL encourage you to study for science lessons; does it} increase your level of interest in the lessons?

The matrix in Table 7 gives an account of the codes established for the responses of students interviewed as a result of the analysis conducted: "I want to study more as I learn by conducting experiments," "I am study as I become curious about the next activity," "I want to study because the science lecture makes science easier".

Table 7. Students' opinions regarding the effect of taking EASL toward studying for the science lessons

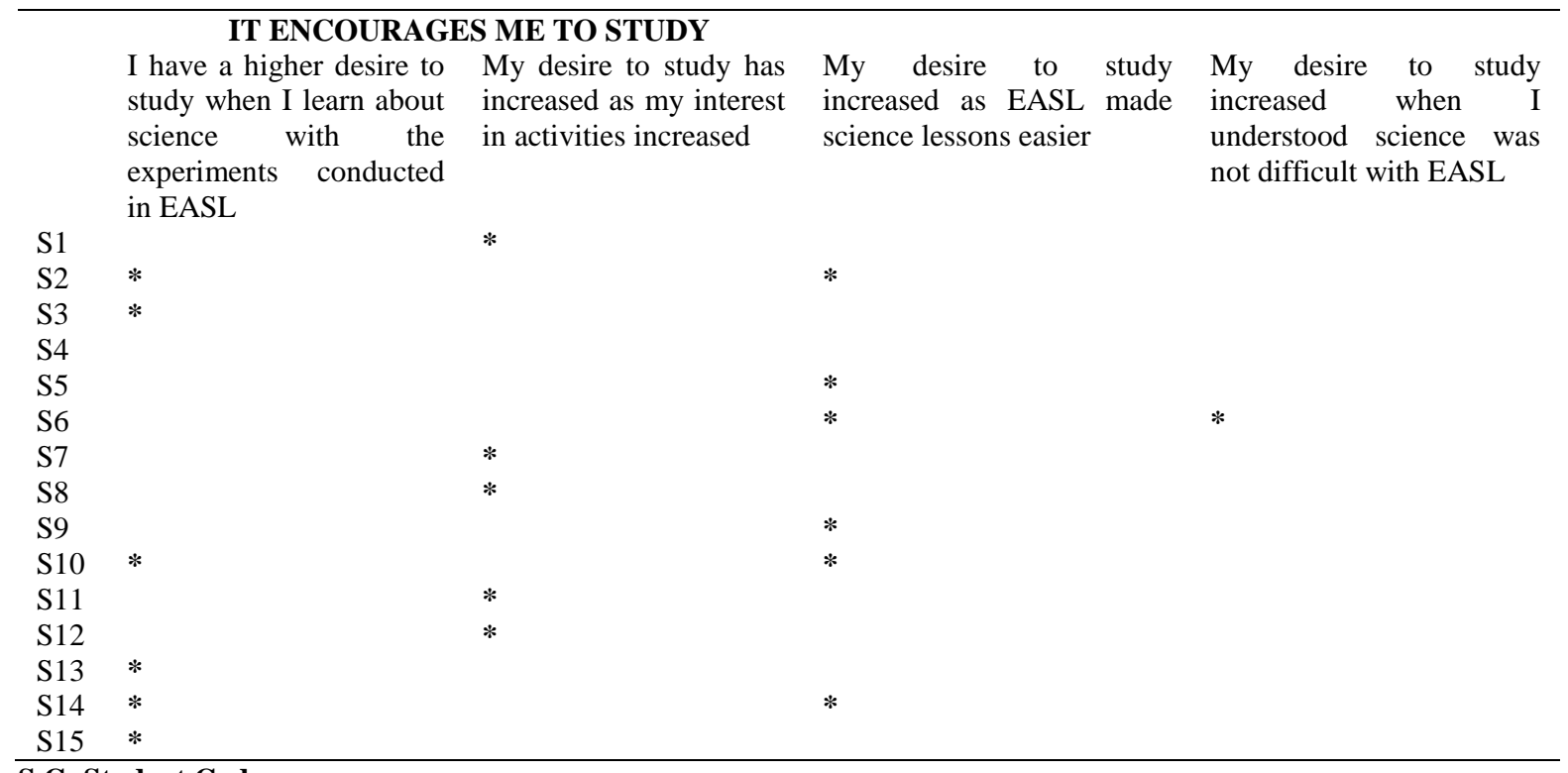

S.C: Student Code

EASL: Elective Science Applications Lecture

An analysis of the students' responses in the interviews found that taking EASL prompted students to study for science lessons by all students. Six students responded with statements similar to, "My desire to study increased when I understood science was not difficult with EASL" to the question 'Does taking EASL encourage you to study for the science lessons, does it increase your level of interest in the lecture?' The comments of student S12, who had stated that EASL has no effect on liking the course and that they did not like to conduct experiments, is given below.

S12: Some of the activities conducted in EASL are very interesting, I am curious about the result, and this raises my interest in some science subjects and increases by desire to study.

\section{Question 8. Would you like to have other science-related topics in the EASL? What are these topics?}

The responses of the students in the interviews were preliminarily codes as YES and NO. The responses of students stating "yes" were coded as "investigating the development of hair roots", "fossils, dinosaurs", "unique animals", "space", "comprehensive electrical", "astronauts" and "living creatures". These codes were used to compile the matrix shown in Table 8. 
Table 8. Opinions of students regarding which other science-related topics in the EASL they

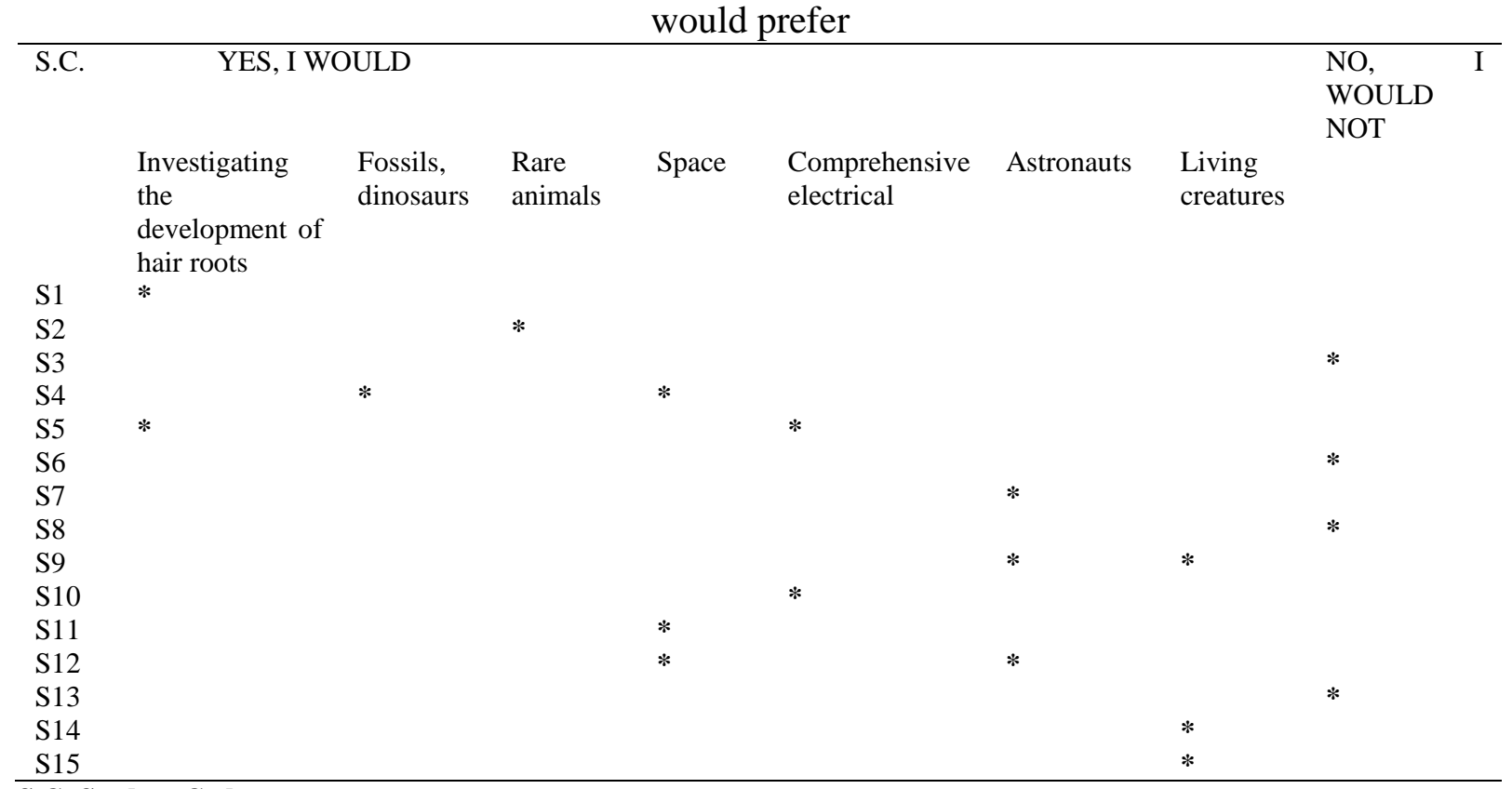

\section{S.C: Student Code}

EASL: Elective Application of Science lessons

A review of Table 8 shows that four out of the 15 interviewed students stated that they did not want to learn other topics, while 11 students stated that they wanted to learn about other topics. Of these topics, three students stated space and astronauts, as the highest ranked topics. Other topics such as "investigating the development of hair roots," "fossils, dinosaurs" and "rare animals" were each stated by one student. Four students stated that there was not a topic that they wanted to undertake.

\section{Question 9. Will you take EASL next year if it is offered? Why?}

Analysis of the students' responses in the interview showed that all the students wanted to take the subject and the codes "It is a lot of fun", "It is preparation of Science", "It ensures higher grades in Science", "It makes Science easier to understand" and "I find it boring but I would take it because it helps me in Science" was established using the responses of students and the matrix in Table 9 was developed.

Table 9. Opinions of students regarding whether they would like to take EASL next year if it

\begin{tabular}{|c|c|c|c|c|c|}
\hline \multirow[t]{2}{*}{ S.C. } & \multicolumn{3}{|c|}{ YES, I WOULD } & \multirow[b]{2}{*}{$\begin{array}{l}\text { Easier to } \\
\text { understand } \\
\text { the science } \\
\text { course }\end{array}$} & \multirow[b]{2}{*}{$\begin{array}{l}\text { I find it boring, but } \\
\text { I would take it } \\
\text { because it helps } \\
\text { me in Science }\end{array}$} \\
\hline & $\begin{array}{l}\text { It is a } \\
\text { lot of } \\
\text { fun }\end{array}$ & $\begin{array}{l}\text { It is preparation } \\
\text { of Science }\end{array}$ & $\begin{array}{l}\text { It ensures } \\
\text { higher } \\
\text { grades in } \\
\text { Science }\end{array}$ & & \\
\hline S1 & $*$ & & & & \\
\hline $\mathrm{S} 2$ & & $*$ & & & \\
\hline S3 & & & $*$ & $*$ & \\
\hline S4 & & & $*$ & $*$ & \\
\hline S5 & $*$ & & & & \\
\hline S6 & & & $*$ & & \\
\hline S7 & & $*$ & & & \\
\hline S8 & & & & $*$ & \\
\hline S9 & $*$ & & & & \\
\hline $\mathrm{S} 10$ & & & & $*$ & \\
\hline
\end{tabular}




\begin{tabular}{lllll}
\hline S11 & $*$ & $*$ & $*$ \\
S12 & $*$ & $*$ & \\
S13 & & & \\
S14 & & & \\
S15 & $*$ & & \\
\hline
\end{tabular}

S.C: Student Code

EASL: Elective Application of Science lessons

A review of Table 9 shows that all the students stated that they wanted to take the course and the most common response to the question why was that it made it "easier to understand the science course." Among the other responses were that it was "a lot of fun," "it is preparation for science," "it ensures higher grades in science" and "boring, but I would take it because it is preparation for Science." The opinions of students coded S12 regarding this question is given below.

\section{I: Would you like to take EASL next year if it is offered? Why?}

S12: Actually I find EASL boring in general, but I would take it because it helps in the preparation for the science lessons.

I: Why do you find it boring?

S12: I want to conduct different activities, not simple experiments.

\section{Discussion and Conclusion}

This study was conducted to investigate the impact of EASL (included in the curriculum in the 2013/14 academic year) on science lessons for 6th Grade students. An examination of study's findings showed that students liked EASL and found it enjoyable. It was found that EASL has a significant impact on the students' enjoyment of science due to making science easier to understand and keeping science knowledge fresh. A study conducted by Kaya and Böyük (2012) with 325 students reports that, although students had an indecisive attitude $(X=2.77)$ toward the subject, science and technology, they showed a positive attitude $(X=3.60)$ toward science experiments conducted within the scope of the study. It is a known fact that, students with a positive attitude towards science lessons have a higher academic performance rate (Demirbaş \& Yağbasan, 2004; Balım, et al., 2009).

It was found in this study that EASL contributes to the learning of science topics, it makes it easier to understand, and contributes to increased student performance in science lessons (Table 3, 4, 5). In a study by Ural Keleş, Aydın and Öner (2015), it was found that EASL makes it easier to learn topics related to science, and another study by Bozdoğan and Şengül (2014) reported that EASL contributed to the cognitive, emotional and psycho-motor skills of students. According to Duvarc1 (2010), the use of a variety of activities has a positive effect on the academic success of students and highlighted that through these means students can acquire many expected behaviors .

In this study it was ascertained that students wanted to take EASL at the next grade and the students also stated that they wanted the lessons to carry out different topics that were of interest to them. Furthermore, the study also showed that EASL increases the motivation of students towards science lessons and increases their desire to learn. Various studies in the literature also state that with EASL student motivation is increased and they become more interested in learning science (Yırtıc1, 2014; Ural Keleş, Aydın \& Öner, 2015). Other studies also show that students have a higher liking for science topics that are learnt through experiments and activities, they have more fun, the motivation of students increase, they become more willing to learn science and students who had previously had no interest become more attentive in class (Telli, et al, 2004; Bilgin, 2006; Akın, 2007; Koç \& Böyük, 
2012).

An important point in the findings of the study is that it was identified that topics, which could not be taught in the science lesson, are frequently undertaken in EASL and activities such as problem solving are frequently the case in EASL. As emphasized by MoNE (2013a), instead of teaching concepts and terminology, EASL should aim for students to discover phenomenon that occurs around them based on scientific foundations by means of various activities while 'having a go' and enjoying themselves. It is also stated in the same source that activities should be conducted by experimentation, research, observation, presentation, and modeling, whenever practically appropriate. A study by Çavuş and Öztuna-Kaplan (2013) found that teachers are guided by the suggestions published in the teaching materials published by MoNE and generally conduct activities and, most often, experiments in EASL. Thus, as was found in this study, as little as it may be, it is clear that to teach the topics for which there is no time in the science lessons and to carry out problem solving activities are an means by which to reach the objectives outlined in the syllabus of this course.

\section{Recommendations}

Within the scope of this qualitative study conducted with 6th Grade students, it was found that EASL has a positive impact on student performance, attitude and motivation for Science courses. However, the lack of a Teacher's Guide Book for EASL makes it difficult for teachers to conduct the lessons according to the objectives outlined in the curriculum. Therefore, the publication of teachers' guide books for all grades and for the course to be taught by subject teachers trained in the relevant sciences will ensure that the lessons will be conducted according to the curriculum.

The study found that the students want to conduct activities in various topics in the EASL. In this regard, the lesson topics may be shaped according to the interest and needs of the students by means of a student needs analysis conducted at the end of the school year.

Further, it is recommended that the effectiveness of the subject can be improved for future years ensuring significant contributions to the science courses if students-teachers-parents work together to identify elective courses and subject area teachers identify and resolve the problems they come across during the teaching process.

\section{References}

Akin, M. F. (2007). The effects of a constructive learning approach on learning success in the teaching of identities. (Unpublished master's thesis). Dicle University, Graduate School of Natural and Applied Science, Diyarbakir.

Balım A. G., Sucuoğlu H. \&Aydın G., (2009). Developing Attitude Scale Journal of Education, 25, 33- 41.

Bilgin I. (2006). The Effects of hands-on activities incorporating a cooperative learning approach on eight grade students' science process skills and attitudes toward science. Journal of Baltic Science Education, 1 (9), 27-37. http://eds.b.ebscohost.com/eds/pdfviewer/pdfviewer?sid=14e0d31a-b907-406a-b60aab02b1f260ef\%40sessionmgr111\&vid=0\&hid=112

Bozdogan, B., Bozdogan, A. E., \& Sengul, Ü. (2014). Examination of Teacher Views About "Implementation Science" Course with Regard to Different Variables. Mersin University Journal of the Faculty of Education, 10(3). 96-109. http://dergipark.ulakbim.gov.tr/mersinefd/article/view/5000033590/0 
Büyüköztürk, Ş., (2004) Sosyal Bilimler İçin Veri Analizi El Kitabı [Handbook of Data Analysis For Social Sciences]. 4. Bask1, Ankara: Pegema Yayıncilik,

Cohen, L. \& Manion, L. (1994). Research Methods in Education. (Fourth Edition), Newyork: Rutledge.

Çavuş,R. \& Öztuna Kaplan, A. (2013, September). Fen Bilimleri Öğretmenlerinin Ortaokul 5. Sınıf Bilim Uygulamaları Dersine Yönelik Görüşleri. 22. Ulusal Eğitim Bilimleri Kurultay1, Eskişehir Osmangazi Üniversitesi, Eskişehir.

Çepni, S. (2009). Araştırma ve Proje Çalışmalarına Giriş [Introduction to Research And Projects Studies]. (Revised Edition). Trabzon: Celepler Matbaacilık

Demirbaş, M., \& Yağbasan, R. (2004). A research on the progress of evaluating affective characteristics in science teaching and the analysis of teachers' practices in teaching process. Journal of Kırşehir Education Faculty 5(2), 177-193. http://kefad.ahievran.edu.tr/archieve/pdfler/Cilt5Sayi2/JKEF_5_2_2004_177_193.pdf

Demirkuş, N. (1999). Fen Bilgisinde Öğretim Yöntemleri ve Uygulamalarının Verimli Hale Getirilmesi. Dokuz Eylül Üniversitesi Buca Eğitim Fakültesi Dergisi Özel Sayı,11, 414-425.

Dinçer A., Şazmaz A., Keleş B., Oral I. \& Sarışık Y.,( 2013). Eğitim İzleme Raporu 2012 [Education Monitoring Report 2012]. Pres: İmak Ofset, İstanbul, Eylül.

Duvarc1, D. (2010). Activity-based chemistry teaching: A case of "elements and compounds". Procedia Social and Behavioral Sciences, 2, 2506-2509. doi:10.1016/j.sbspro.2010.03.362.

http://www.sciencedirect.com/science/article/pii/S1877042810004027

Eke, C.(2013). Seçmeli "bilim uygulamalari” dersinin fen bilimlerinin öğretimi açisindan önemi. Journal of Research in Education and Teaching. Say1,2, 21. http://dergipark.ulakbim.gov.tr/mersinefd/article/view/5000033590/0

Hançer, A. H., Şensoy. \& Yıldırım, H. İ.(2003). An evalation about the importance of contemporary science education at elemantary schools and how this kind of science teaching must be, Pamukkale University Journal of Education,13,80-88.

file:///C:/Users/PROBOOK/Downloads/5000056325-5000074395-1-PB\%20(2).pdf

Kaya, H. \& Böyük U. (2012). Attitudes towards science and technology cours and science experiments of the elementary school's 2nd grade students, Tübav Bilim Dergisi 4(2) 120-130.

file:///C:/Users/PROBOOK/Downloads/136-341-1-PB.pdf

Koç A. \& Böyük U. (2012). The Effect of Hands-on Science Experiments on Attitude towards Science, Journal of Turkish Science Education 9(4) 102-118. http://search.proquest.com/openview/598e047d1403c14fd72683363ee56b0a/1?pqorigsite $=$ gscholar

MEB. (2013a). İlköğretim Kurumları (İlkokullar ve Ortaokullar) Fen Bilimleri Dersi (3, 4, 5, 6, 7 ve 8. Sınıflar) Öğretim Programı [Primary Schools (Primary and Secondary Schools) Science Course (3, 4, 5, 6, 7 and 8th Grades) Curriculum]., Ankara:

Ministry of National Education www.mku.edu.tr/getblogfile.php?keyid=2429.

MEB. (2013b). Ortaokul ve İmam Hatip Ortaokulu Bilim Uygulamaları Dersi (5, 6, 7 Ve 8. Sinıflar) Öğretim Programı. .[ Secondary School and Imam Hatip Middle School Science Applications Course (5, 6, 7 and 8th Grades) Curriculum]. Ankara:Ministry of National Education. http://ttkb.meb.gov.tr/dosyalar/programlar/ilkogretim/bilimuygulamalari_ort.pdf

Tekbıyı, A. ve Akdeniz, A.R.(2008). Teachers' Views about Adoption and Application of Primary Science and Technology Curriculum. Necatibey Faculty of Education Electronic Journal of Science and Mathematics Education, Vol. 2, Issue 2, pp. 23-37. http://dergipark.ulakbim.gov.tr/balikesirnef/article/view/5000084754/5000078836 
Telli, A., Yıldırım ,İ. H., Şensoy, Ö., \& Yalçın, N. (2004). A Study on the Effect of Use of Experimental Method in Teaching the Topic of Simple Machines on 7th Grade Primary School Students' Achievement, Gazi University Journal of Gazi Educational Faculty, 3, 291-305.

Ural Keleş, P., Aydin, S. ve Öner. A. (2015). The Opinions Of Sixth Grade Students Regarding The Elective Science Applications Class. Jokull Journual, 65(1), 100-116.

URL 1 http://kumlu.meb.gov.tr/meb_iys_dosyalar/ 15/05/2014.

Wellington, J., (2000). Educational Research, Continuum, London and New York

Yerer, H., Bektaş, O., ve Öner Armağan, F. (2013). Bilim Uygulamaları' ve 'Çevre ve Bilim' Seçmeli Derslerinin İçeriği Hakkında Fen Bilimleri Öğretmenlerinin Görüşleri, Erciyes University, Institue of Journal Social Sciences, 35(2), 72-94. http://sbedergi.erciyes.edu.tr/35.sayi/makale/5-Handan\%20Yerer\%20(7294.\%20s).pdf

Yirtic1, Z. (2014). Impact of optional courses of scientific application on students'scientific process skills and motivations towards science. (Unpublished master's thesis). Gazi University The Graduate School of Educational Sciences, Ankara. 